\title{
Design and synthesis of some isoindoline derivatives as analogues of the active anti-inflammatory Indoprofen
}

\author{
Ferenc Csende, ${ }^{a}{ }^{*}$ Ferenc Miklós, ${ }^{b}$ and Andrea Porkoláb ${ }^{a}$ \\ ${ }^{a}$ Taxus Research Laboratory, Bocskai u. 22, H-4080 Hajdúnánás, Hungary \\ ${ }^{b}$ Institute of Pharmaceutical Chemistry, University of Szeged, Eötvös u. 6, \\ H-6720 Szeged, Hungary \\ E-mail: csende@nanaskabel.hu
}

\section{Dedicated to Professor Richard R. Schmidt on the occasion of his 78th anniversary}

\begin{abstract}
Searching new targets for anti-inflammatory drug design, agents with the isoindole skeleton were focused on the basis of preliminary studies of NSAIDs as COX-1 and/or COX-2 enzyme inhibitors. Thus several novel $\mathrm{N}$-substituted isoindoline derivatives as possible biologically active compounds were prepared as analogues of Indoprofen (1) starting from cis-2-[(4methylphenyl)carbonyl]cyclohexanecarboxylic acid (3) by treatment with primary arylamines.
\end{abstract}

Keywords: Isoindoles, NSAIDs, cyclooxygenase (COX), enzyme inhibition, Indoprofen analogues, molecular modeling

\section{Introduction}

Recently we described preparation, behaviour and structural studies of several substituted or fused isoindole derivatives. Their important and remarkable pharmacological properties also were reported. $^{1 \mathrm{a}-\mathrm{f}}$ In continuation and extension of our synthetic and structural studies of saturated and partially saturated isoindoles we have designed and prepared Indoprofen ${ }^{2 \mathrm{a}-\mathrm{d}}$ analogues. Indoprofen (1) is a nonsteroidal anti-inflammatory and analgesic drug, which was withdrawn worldwide in the 1980s after postmarketing reports of severe gastrointestinal bleeding. However in a more recent study Indoprofen is reported to increase production of the survival of motor neurone protein, suggesting it may provide insight into treatments for spinal muscular atrophy. ${ }^{3 \mathrm{a}}$ Moreover, Ellies et al. have found that Indoprofen and its derivatives promote bone growth. ${ }^{3 b}$ Based on the structural features of Indoprofen, a series of isoindol-1-one derivatives were designed and synthesized, and all showed very good binding affinities, with $\mathrm{K}_{\mathrm{i}}$ values in the subnanomolar $(\mathrm{nM})$ range against aggregated $\mathrm{A} \beta 42$ fibrils. Thus these compounds 
could serve as scaffolds for potential Alzheimer's disease (AD) diagnostic probes to monitor A $\beta$ fibrils. ${ }^{3 \mathrm{c}}$ The Indoprofen derivatives also possess prostanoid $\mathrm{EP}_{4}$ receptor agonist properties and regulate inflammatory cytokines after an inflammatory stimulus. ${ }^{3 \mathrm{~d}}$ These results prompted us to prepare the optimized drug candidates 3-aryl substituted and partially saturated isoindolone derivatives, developing new potential anti-inflammatory drugs associated with lower gastrointestinal (GI) side-effects (e.g. gastritis, peptic ulceration, gastric bleeding). Earlier several 1,3-diarylisoindole ${ }^{4 \mathrm{a}}$ and isoindole-1,3-dione (phthalimide) ${ }^{4 \mathrm{~b}, \mathrm{c}}$ derivatives were developed, evaluated and studied in detail as potent anti-inflammatory agents and selective COX-2 inhibitors. According to a comparison of the structures of the non-selective Indoprofen (1) and the selective COX-2 inhibitor Celecoxib (2) below, some modifications were required to reduce the side-effects (with gastric tolerance and without cardiovascular risks) keeping the potent anti-inflammatory activity of the compounds (Figure 1).

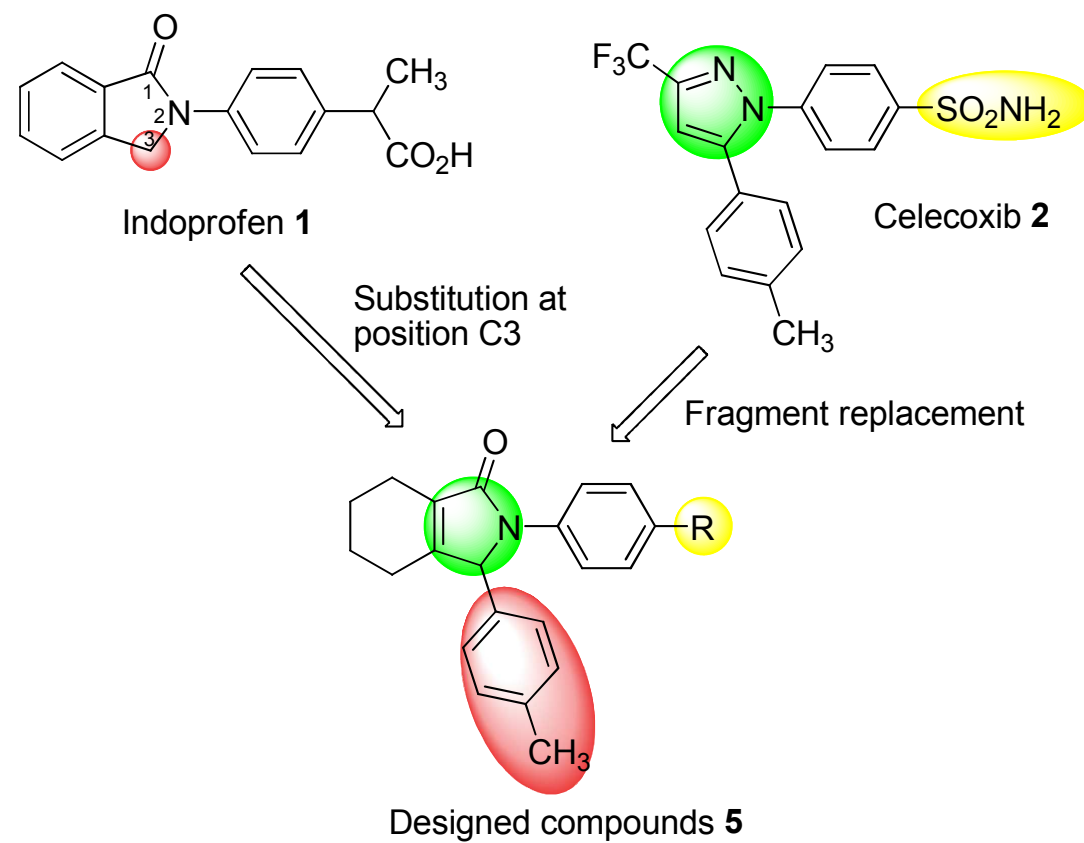

Figure 1. Structural rationalization and optimization strategy of designed compounds 5.

In the course of structural modification, Indoprofen (1) as a base molecule was substituted with an aryl group (red region) at the position $\mathrm{C} 3$ in the isoindole ring, a moiety important in Celecoxib (2) for the COX-2 selectivity. Furthermore, the aryl group increases the lipophilicity (giving higher $\log \mathrm{P}$ values), and hence could improve the anti-inflammatory activity of the target molecules. Replacement of the pyrazole core of Celcoxib by 2-pyrrolidone resulted in the hybrid molecules 5. Introduction of several substituents (e.g. $\mathrm{R}=\mathrm{OH}, \mathrm{CO}_{2} \mathrm{H}, \mathrm{CONH}_{2}$ ) into the $\mathrm{N}$-phenyl group also influences the biophysical and pharmacological properties. Molecular docking studies support the presumption that our designed compounds after physicochemical screening may act on the same enzyme target as the COX-2 inhibitors. 


\section{Results and Discussion}

In continuation of our research program to develop new partially saturated isoindole derivatives which could be pharmacologically useful, the $\gamma$-ketocarboxylic acid $\mathbf{3}$ was reacted with different bifunctional alkyl or aryl amines, either in a refluxing non-polar solvent (toluene, xylene) or neat in a solvent-free fusion reaction at $180-200{ }^{\circ} \mathrm{C}$ (Scheme 1), to obtain functionalized $\mathrm{N}$-aryl-3-oxo-1,3,4,5,6,7-hexahydro- $2 \mathrm{H}$-isoindoles (5a-h) in a one-step reaction. In this way novel $N$-aryl substituted isoindolones were synthesized by the reaction of substituted aniline derivatives with the oxocarboxylic acid $\mathbf{3}$ under the above conditions first of all. Thus,

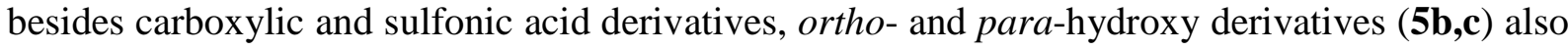
were prepared, which can be interesting as paracetamol analogues. Recently, compounds $5 \mathbf{a}$ and 5c were synthesized and characterized, however as possible anti-inflammatory candidates were not investigated. ${ }^{\mathrm{la}, \mathrm{b}}$ The physicochemical and structural characterization of the title compounds are described in the Experimental section in detail. The proposed and main mechanism of action of these nonsteroidal compounds (e. g. phenylacetic- or propionic acid derivatives and sulfonamides, coxibs) base on the inhibition of cyclooxygenase (COX), and recent findings suggest that it is highly selective for COX-2 enzyme. ${ }^{6}$

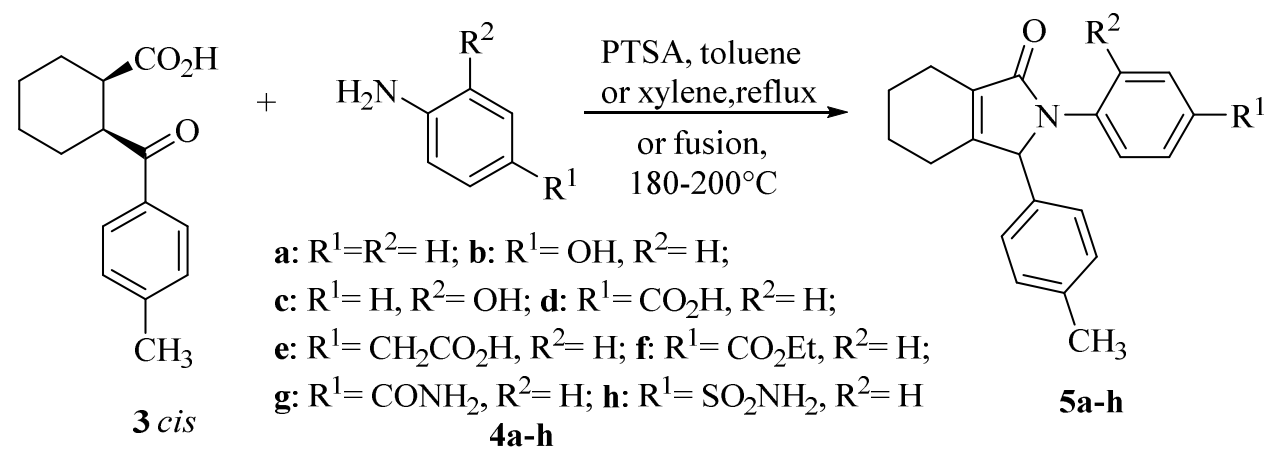

Scheme 1. Synthesis of 3-(4-methylphenyl)- $N$-arylhexahydro- $1 H$-isoindol-1-ones (5a-h).

Superimposition of Indoprofen (1), Celecoxib (2), and compound 5e showed remarkable similarities (Figure 2). Therefore we supposed that $5 \mathbf{e}\left(\mathrm{R}^{1}=\mathrm{CH}_{2} \mathrm{CO}_{2} \mathrm{H}, \mathrm{R}^{2}=\mathrm{H}\right)$ may be a COX-2 selective agent. We found that overlapping of the investigated compounds could lead to a novel series of potential anti-inflammatory compounds with little modification of the lead compound Indoprofen (1). 


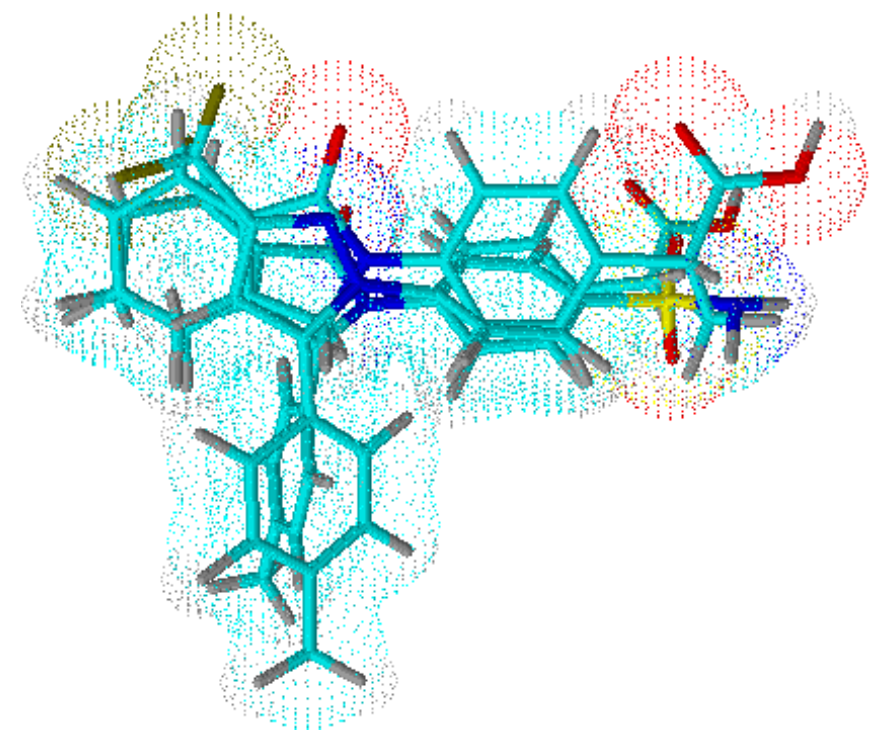

Figure 2. Superimposition of compounds of Indoprofen (1), Celecoxib (2) and 5e and their van der Waals surfaces.

A very useful docking study was described earlier concerning the NSAID/ COX-2 isozyme complexes. ${ }^{7}$ According to this work we modeled and docked the Celecoxib 2 and isoindole derivative 5e with the schematic COX-2 isozyme (Figure 3). The traditional docking procedure was used by the identification of optimized formation of molecules, the binding site and structure of protein-ligand complexes. The ligands were drawn using ChemBioDraw Ultra 11.0 (Cambridge Soft; 100 CambridgePark Drive, Cambridge, MA 02140 USA) program and converted to the most favourable three-dimensional format using ACD/3D Viewer Freeware (Version 12.01) software (Advanced Chemistry Development, Inc.; ACD Labs, Toronto, Canada; the program is available at the ACD Labs at www.acdlabs.com). The top score ligandreceptor docking was demonstrated by $2 \mathrm{D}$ representation of complex interactions. The structural basis and conformational changes of cyclooxygenase-2 (COX-2) enzyme and its complexes with some anti-inflammatory agents has been described earlier in detail. ${ }^{8}$ The carboxylate group of $\mathbf{5 e}$ can be located in cavity B and cavity C. Delocated electrons of phenylacetic groups with Arg120 amino acid gives traditional NSAIDs the same anchor point in COX-1 and COX-2 enzymes and thus limits their selectivity; however, a strong hydrogen bond between of valine (Val523) amino acid and carboxy group could increase the COX-2 selectivity. On the other hand the presence of the 4-methylphenyl substituent increases the lipophilicity of the molecule and locates at the end of cavity A at the lipophilic site of the aromatic tryptophan part (Trp387). Unfortunately, according to a modeling study at the cavity $\mathrm{C}$, compound $\mathbf{5 e}$ does not interact with amino acids His90, Arg513 and Gln192 by hydrogen bonding, which is an important key for COX-2 selectivity, while a bond with Tyr355 reinforces the interaction of the inhibitor with the enzyme. Finally, molecule $\mathbf{5 h}\left(\mathrm{R}^{1}=\mathrm{SO}_{2} \mathrm{NH}_{2}\right)$ was found to be a more selective COX-2 inhibitor closely analogous to Celecoxib (2) after replacement of the para substituent of $\mathbf{5 e}\left(\mathrm{R}^{1}=\mathrm{CH}_{2} \mathrm{CO}_{2} \mathrm{H}\right)$ by a 
sulfonamide group (5h), when Phe518, His90 and Arg513 amino acids were activated in the cavity $\mathrm{C}$ of the enzyme, however the in silico test showed less bioactivity.
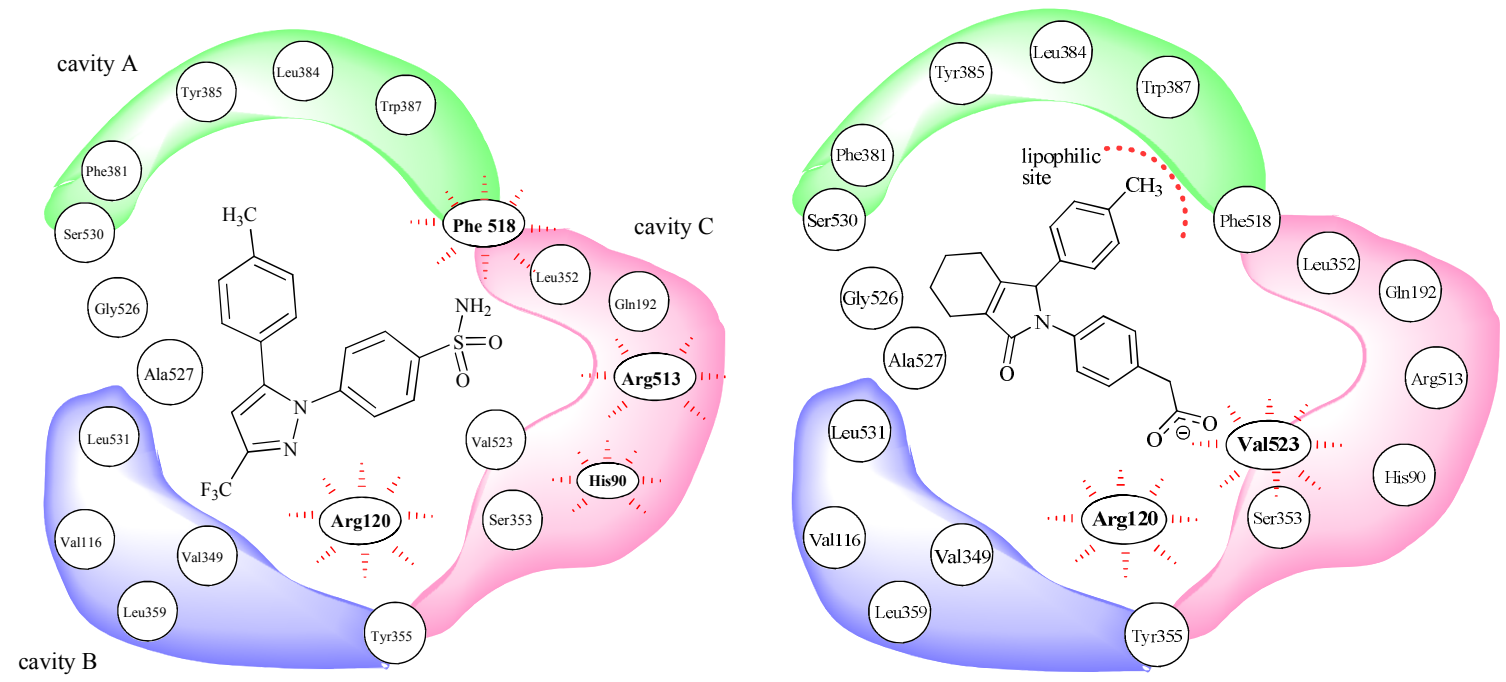

Figure 3. Schematic proposed representation and comparison of optimal positions of the ligand/COX-2 key as inferred from molecular modeling for compounds Celecoxib (2) and 5e.

Using the semi-empirical quantum-mechanical method AM1, the molecular geometries of the benzofuran analogues of anti-inflammatory arylalkanoic acids were calculated, then optimized, and their frontier orbital charge distribution evaluated. ${ }^{9 a}$ The physicochemical properties (conformation, protonation energy, lipophilicity) of some arylpropionic acids also were determined theoretically by using quantum-mechanical calculations and correlated with their anti-inflammatory activity. ${ }^{9 \mathrm{~b}}$ In our case the structures were also studied by molecular modeling and the conformational protocol using ACD/ChemSketch Freeware (Version 12.01) software (Advanced Chemistry Development, Inc.; ACD Labs,Toronto, Canada) for compounds 1, 2 and isoindolones 5a-5h. The physical-chemical properties, such as molecular polar surface (PSA), calculated lipophilicity $(c \cdot \log \mathrm{P})$, acidity $\left(\mathrm{pK}_{\mathrm{a}}\right)$, molecular volume $\left(\AA^{3}\right)$ moreover the druglikeness and bioactivity scores were calculated using the freely accessible Molinspiration Cheminformatics Software (www.molinspiration.com; Slovensky Grob, Slovak Republic). The main calculated or predicted physical-chemical properties of the above compounds are summarized in Table 1. 
Table 1. Some calculated physical-chemical properties of the investigated compounds

\begin{tabular}{|c|c|c|c|c|c|c|c|}
\hline compound & $\mathrm{R}^{1}$ & $\mathrm{R}^{2}$ & $\operatorname{clog} \mathrm{P}^{a}$ & $\operatorname{clog} \mathrm{P}^{b}$ & $\mathrm{pK}_{\mathrm{a}}$ & $\operatorname{PSA}^{c}\left(\AA^{2}\right)$ & $\operatorname{MV}^{d}\left(\AA^{3}\right)$ \\
\hline 1 & - & - & $2.77 \pm 0.47$ & 2.883 & 3.7 & 57.61 & 253.569 \\
\hline 2 & - & - & $4.21 \pm 1.49$ & 3.611 & 11.1 & 77.98 & 298.650 \\
\hline $5 \mathbf{a}$ & $\mathrm{H}$ & $\mathrm{H}$ & $4.53 \pm 0.60$ & 5.061 & - & 20.31 & 293.549 \\
\hline $5 \mathbf{b}$ & $\mathrm{OH}$ & $\mathrm{H}$ & $3.79 \pm 0.84$ & 4.581 & 9.3 & 40.54 & 301.566 \\
\hline $5 c$ & $\mathrm{H}$ & $\mathrm{OH}$ & $3.79 \pm 0.84$ & 4.793 & 8.6 & 40.54 & 301.566 \\
\hline $5 d$ & $\mathrm{CO}_{2} \mathrm{H}$ & $\mathrm{H}$ & $4.21 \pm 0.85$ & 4.971 & 4.1 & 57.61 & 320.550 \\
\hline $5 e$ & $\mathrm{CH}_{2} \mathrm{CO}_{2} \mathrm{H}$ & $\mathrm{H}$ & $3.82 \pm 0.61$ & 4.486 & 3.8 & 57.61 & 337.352 \\
\hline $5 f$ & $\mathrm{CO}_{2} \mathrm{Et}$ & $\mathrm{H}$ & $5.04 \pm 0.85$ & 5.478 & - & 46.61 & 371.681 \\
\hline $5 g$ & $\mathrm{CONH}_{2}$ & $\mathrm{H}$ & $3.05 \pm 0.85$ & 3.880 & 14.3 & 63.40 & 323.821 \\
\hline $5 \mathrm{~h}$ & $\mathrm{SO}_{2} \mathrm{NH}_{2}$ & $\mathrm{H}$ & $2.64 \pm 0.85$ & 3.755 & 9.7 & 80.47 & 336.269 \\
\hline
\end{tabular}

${ }^{a}$ Calculated $\log \mathrm{P}$ by using $\mathrm{ACD} / \mathrm{Labs}$ software; ${ }^{b}$ Calculated $\log \mathrm{P}$ by using Molinspiration Cheminformatics software; ${ }^{c} \mathrm{PSA}=$ Polar surface area; ${ }^{d} \mathrm{MV}=$ Molecular volume.

Table 2. Drug-likeness and bioactivity scores of compounds 1, $\mathbf{2}$ and $\mathbf{5 a - h}$ according to the Molinspiration Cheminformatics software

\begin{tabular}{ccccccc}
\hline Comp. & GPCR lig. $^{a}$ & ${\text { Ion c. } .^{b}}^{b}$ & Kinase inh. $^{c}$ & Nucl. r.l. $^{d}$ & Prot. inh. $^{e}$ & Enzyme inh. $^{f}$ \\
\hline $\mathbf{1}$ & 0.26 & -0.04 & -0.03 & 0.21 & -0.09 & 0.28 \\
$\mathbf{2}$ & -0.06 & -0.27 & 0.01 & -0.28 & -0.06 & 0.17 \\
$\mathbf{5 a}$ & -0.48 & -0.58 & -0.62 & -0.33 & -0.54 & -0.51 \\
$\mathbf{5 b}$ & -0.41 & -0.51 & -0.55 & -0.16 & -0.49 & -0.44 \\
$\mathbf{5 c}$ & -0.40 & -0.66 & -0.60 & -0.23 & -0.54 & -0.46 \\
$\mathbf{5 d}$ & -0.41 & -0.52 & -0.58 & -0.14 & -0.43 & -0.39 \\
$\mathbf{5 e}$ & -0.27 & -0.40 & -0.55 & 0.00 & -0.28 & -0.28 \\
$\mathbf{5 f}$ & -0.43 & -0.47 & -0.64 & -0.20 & -0.39 & -0.43 \\
$\mathbf{5 g}$ & -0.41 & -0.58 & -0.43 & -0.39 & -0.38 & -0.42 \\
$\mathbf{5 h}$ & -0.50 & -0.59 & -0.55 & -0.49 & -0.28 & -0.32 \\
\hline
\end{tabular}

${ }^{a}$ GPCR ligand; ${ }^{b}$ Ion channel modulator; ${ }^{c}$ Kinase inhibitor; ${ }^{d}$ Nuclear receptor ligand;

${ }^{e}$ Protease inhibitor; ${ }^{f}$ Enzyme inhibitor. 
The drug-likeness and bioactivity score of the investigated compounds as NSAID candidate agents also were predicted computionally using the Molinspiration Cheminformatics software. This method was realized on the basis of the sophisticated Bayesian statistics to compare structures of representative ligands active on the particular target with structures of inactive molecules and to indentify substructure features typical for active molecules.

The activity scores for the six most important drug classes were compared with average druglike molecules. Thus calculation of drug-likeness score towards GPCR ligands, ion channel modulator, kinase inhibitors, nuclear receptor inhibitors and other enzyme targets based on Molinspiration Cheminformatics software by "on-line test". The larger the value of the score is, the higher is the probability that the particular molecule will be active. These drug-likeness and bioactivity results are summarized in Table 2 and the scores allow adequate identification of active and inactive molecules. The values which are depicted in red may refer to considerable biological activities (bioactivity scores $\geq 0.00$ ), while green values (bioactivity scores $\geq-0.28$ ) display fewer similarities to the known drugs and less efficiency of drug-like molecules. The black values show presumed inactivity of compounds investigated.

\section{Conclusions}

The comparison of the well-known NSAID Indoprofen (1) the COX-2 selective Celecoxib (2) and novel aryl-substituted isoindolone derivatives (5a-h) proved the importance of design, synthesis and further search of new anti-inflammatory drugs which are exempt from the undesirable side-effects. The present results showed that variations of the substitution and the heterocyclic moieties led to remarkable changes in the pharmacological, physical and biochemical properties. As it was expected, compound 5e had the most remarkable calculated biological activity similar to Indoprofen (1) (Table 2), however application of the above results require carefulness and further modifications of substituents at isoindoline ring should be desirable. The pharmacological investigation of these compounds is in progress and will be reported in due course.

\section{Experimental Section}

General. Melting points were determined in open glass capillaries using an Electrothermal melting point apparatus and are uncorrected. Infrared spectra were recorded for $\mathrm{KBr}$ discs with Perkin-Elmer 177 instrument. ${ }^{1} \mathrm{H}$ NMR and ${ }^{13} \mathrm{C}$ NMR spectra were recorded on a Bruker Avance DRX $400 \mathrm{MHz}$ spectrometer and $\mathrm{CDCl}_{3}$ or DMSO- $d_{6}$ were used as solvent. Chemical shifts $(\delta)$ are in ppm from tetramethylsilane (TMS) as internal standard, coupling constants ( $J$ values) are in $\mathrm{Hz}$. Ascending TLC for the retention factor $\left(\mathrm{R}_{\mathrm{f}}\right)$ was performed on precoated plates of silica 
gel 60F 254 (Merck), the mobile phase was a mixture of and benzene-EtOH- $n$-hexane (4:1:3) and spots were visualized by using a UV lamp or iodine vapor.

Preparation of 3-tolyl-2-phenylhexahydroisoindol-1-ones (5a-c and 5g) by method A. To a solution of the oxocarboxylic acid $3^{1 \mathrm{a}}(2.46 \mathrm{~g}, 0.01 \mathrm{~mol})$ in dry toluene or xylene $(30 \mathrm{ml})$ were added the corresponding amine $(0.015 \mathrm{~mol})$ and $p$-toluenesulfonic acid (PTSA) $(0.10 \mathrm{~g})$. The mixture was then heated in an oil bath under a Dean-Stark apparatus to reflux for 3-6 h. The reaction mixture was evaporated and the residue was purified by crystallization or by column chromatography with chloroform, then EtOAc eluent, on silica gel. The collected fractions were evaporated and the residue was treated with diethyl ether $(15 \mathrm{~mL})$ and kept in a refrigerator overnight. The material was collected and recrystallized from diethyl ether to give compounds $\mathbf{5}$ as white crystalline solids.

Preparation of 3-tolyl-2-phenylhexahydroisoindol-1-ones (5d-f and 5h) by Method B. In a round-bottom flask, a mixture of oxocarboxylic acid $3(2.46 \mathrm{~g}, 0.01 \mathrm{~mol})$ and an excess of aryl amine $4(0.012 \mathrm{~mol})$ was heated at $180-200{ }^{\circ} \mathrm{C}$ for 3 hours. After cooling to room temperature the mixture was solved in chloroform and purified by column chromatography (silica gel packing, chloroform and EtOAc eluent) to obtain compounds $\mathbf{5}$ as white crystalline solids.

3-(4-Methylphenyl)-2-phenyl-2,3,4,5,6,7-hexahydro-1H-isoindol-1-one (5a). ${ }^{\text {a,b }}$ (Method A) Yield: $81 \%$, white crystals, mp. $155-157{ }^{\circ} \mathrm{C}(\mathrm{EtOH}) . \mathrm{R}_{f}: 0.58 .{ }^{1} \mathrm{H}$ NMR $\left(\mathrm{CDCl}_{3}\right): \delta 1.50-1.95$ (m, 5H), 2.10-2.40 (m, 3H), $2.25\left(\mathrm{~s}, 3 \mathrm{H}, \mathrm{CH}_{3}\right) 5.35(\mathrm{~s}, 1 \mathrm{H}, \mathrm{ArCH}), 6.93-7.12(\mathrm{~m}, 5 \mathrm{H}, \mathrm{ArH}), 7.22$ $(\mathrm{d}, J 7.1 \mathrm{~Hz}, 2 \mathrm{H}), 7.52$ (d, J 7.9 Hz, 2H). ${ }^{13} \mathrm{C} \mathrm{NMR}\left(100.6 \mathrm{MHz} \mathrm{CDCl}_{3}\right)$ 21.3, 21.6, 21.9, 22.2, 22.8, 67.2, 126.8, 127.5, 128.0, 128.8, 128.9, 133.2, 136.4, 140.2, 155.1, 165.5. IR $\left(\mathrm{cm}^{-1}\right): 2917$, 1666, 1498, 1355, 1105. Anal. Calcd for $\mathrm{C}_{21} \mathrm{H}_{21} \mathrm{NO}$ : C, 83.23; H, 6.98; N, 4.62. Found C, 83.48; $\mathrm{H}, 7.02 ; \mathrm{N}, 4.70 \%$.

2-(4-Hydroxyphenyl)-3-(4-methylphenyl)-2,3,4,5,6,7-hexahydro-1H-isoindol-1-one

(5b). (Method A) Yield: 79\%, white crystals, mp. 242-244 ${ }^{\circ} \mathrm{C}(\mathrm{EtOH}) . \mathrm{R}_{f}: 0.27 .{ }^{1} \mathrm{H}$ NMR (DMSO$\left.d_{6}\right): \delta 1.65-1.74(\mathrm{~m}, 4 \mathrm{H}), 1.89-1.92(\mathrm{~m}, 1 \mathrm{H}), 2.17-2.21(\mathrm{~m}, 1 \mathrm{H}), 2.31\left(\mathrm{~s}, 3 \mathrm{H}, \mathrm{CH}_{3}\right), 2.37(\mathrm{~m}, 2 \mathrm{H})$, 5.66 (s, 1H, ArCH), 6.60-6.63 (m, 2H, ArH), 7.02-7.10 (m, 4H), 7.22-7.25 (m, 2H), $9.17(\mathrm{~s}, 1 \mathrm{H}$, $\mathrm{OH}) .{ }^{13} \mathrm{C}$ NMR (100.6 MHz, $\left.\mathrm{CDCl}_{3}\right)$ 20.7, 21.5, 22.3, 22.5, 23.5, 69.7, 77.1, 77.4, 77.7, 116.4, 125.3, 127.5, 130.0, 131.2, 133.2, 138.4, 154.3, 155.6. IR ( $\left.\mathrm{cm}^{-1}\right): 3191,1683,1516,1369,1127$. Anal. Calcd for $\mathrm{C}_{21} \mathrm{H}_{21} \mathrm{NO}_{2}$ : C, 78.88; H, 6.62; N, 4.38. Found C, 78.68; H, 6.85; N, 4.56\%.

2-(2-Hydroxyphenyl)-3-(4-methylphenyl)-2,3,4,5,6,7-hexahydro-1 $H$-isoindol-1-one $\quad(5 \mathrm{c}) .^{\text {b }}$ (Method A) Yield: $76 \%$, white crystals, mp. 176-177 ${ }^{\circ} \mathrm{C}(\mathrm{EtOH}) . \mathrm{R}_{f}: 0.34 .{ }^{1} \mathrm{H} \mathrm{NMR}\left(\mathrm{CDCl}_{3}\right): \delta$ 1.60-2.05 (m, 5H), 2.18-2.42 (m, 3H), $2.24\left(\mathrm{~s}, 3 \mathrm{H}, \mathrm{CH}_{3}\right) 5.61(\mathrm{~s}, 1 \mathrm{H}, \mathrm{ArCH}), 6.70-6.82(\mathrm{~m}, 1 \mathrm{H}$, ArH), 6.93-7.10 (m, 7H), $8.72(\mathrm{~s}, 1 \mathrm{H}, \mathrm{OH}) .{ }^{13} \mathrm{C} \mathrm{NMR}\left(100.6 \mathrm{MHz}, \mathrm{CDCl}_{3}\right)$ 21.3, 21.6, 21.9, 22.2, 22.8, 67.5, 116.1, 117.5, 122.6, 125.2, 126.2, 127.6, 128.3, 133.0, 136.1, 140.8, 149.7, 155.3, 165.0. IR $\left(\mathrm{cm}^{-1}\right): 2925,1679,1510,1226$, 995. Anal. Calcd for $\mathrm{C}_{21} \mathrm{H}_{21} \mathrm{NO}_{2}: \mathrm{C}, 78.96 ; \mathrm{H}$, $6.62 ; \mathrm{N}, 4.38$. Found C, 79.19; H, 6.80; N, 4.51\%.

4-[1-(4-Methylphenyl)-3-oxo-1,3,4,5,6,7-hexahydro-2H-isoindol-2-yl]benzoic acid (5d). (Method B) Yield: 64\%, white powder, mp 195-197 ${ }^{\circ} \mathrm{C}$ (benzene) $\mathrm{R}_{f}: 0.41 .{ }^{1} \mathrm{H} \mathrm{NMR}\left(\mathrm{CDCl}_{3}\right): \delta$ 
1.64-1.96 (m, 5H), 2.22-2.41 (m, 3H), $2.26\left(\mathrm{~s}, 3 \mathrm{H}, \mathrm{CH}_{3}\right) 5.57(\mathrm{~s}, 1 \mathrm{H}, \mathrm{ArCH}), 6.96-7.07(\mathrm{~m}, 2 \mathrm{H}$, ArH), 7.19-7.54 (m, 6H), 10.72 (s, br, $1 \mathrm{H}, \mathrm{COOH}) .{ }^{13} \mathrm{C} \mathrm{NMR}\left(100.6 \mathrm{MHz}, \mathrm{CDCl}_{3}\right)$ 20.9, 21.4, 22.3, 22.6, 68.7, 121.8, 126.7, 127.6, 130.8, 133.3, 137.9, 155.3, 165.8, 168.7. IR $\left(\mathrm{cm}^{-1}\right): 3072$, 1947, 1686, 1654, 1208, 916. Anal. Calcd for $\mathrm{C}_{22} \mathrm{H}_{21} \mathrm{NO}_{3}$ : C, 76.06; H, 6.09; N, 4.03. Found C, $76.14 ; \mathrm{H}, 6.15 ; \mathrm{N}, 4.20 \%$.

[4-[1-(4-Methylphenyl)-3-oxo-1,3,4,5,6,7-hexahydro-2H-isoindol-2-yl]phenyl]acetic acid (5e). (Method B) Yield: 59\%, white powder, mp.185-186 ${ }^{\circ} \mathrm{C}(\mathrm{EtOH}) . \mathrm{R}_{f}: 0.48 .{ }^{1} \mathrm{H} \mathrm{NMR}$ $\left(\mathrm{CDCl}_{3}\right): \delta 1.67-1.95(\mathrm{~m}, 5 \mathrm{H}), 2.17-2.39(\mathrm{~m}, 3 \mathrm{H}), 2.28\left(\mathrm{~s}, 3 \mathrm{H}, \mathrm{CH}_{3}\right) 3.69\left(\mathrm{~s}, 2 \mathrm{H}, \mathrm{CH}_{2}\right), 5.58(\mathrm{~s}$, 1H, ArCH), 6.98-7.13 (m, 4H, ArH), 7.22 (d, J 7.5 Hz, 2H), 7.34 (d, J 7.2 Hz, 2H) 10.84 (s, br, $1 \mathrm{H}, \mathrm{COOH}) .{ }^{13} \mathrm{C} \mathrm{NMR}\left(100.6 \mathrm{MHz}, \mathrm{CDCl}_{3}\right)$ 20.4, 21.3, 22.2, 22.6, 23.5, 42.3, 68.3, 125.8, 127.3, 128.2, 130.2, 133.9, 136.6, 138.7, 140.4, 155.4, 165.7, 180.5. IR (cm $\left.{ }^{-1}\right): 2966,1725,1659$, 1226, 672. Anal. Calcd for $\mathrm{C}_{23} \mathrm{H}_{23} \mathrm{NO}_{3}$ : C, 76.43; H, 6.41; N, 3.88. Found C, 76.29; H, 6.55; N, $4.01 \%$.

Ethyl 4-[1-(4-methylphenyl)-3-oxo-1,3,4,5,6,7-hexahydro-2 $H$-isoindol-2-yl]benzoate (5f). (Method B) Yield: 68\%, white powder, m p. 142-144 ${ }^{\circ} \mathrm{C}$ (benzene). $\mathrm{R}_{f}: 0.61 .{ }^{1} \mathrm{H} \mathrm{NMR}\left(\mathrm{CDCl}_{3}\right)$ : $\delta 1.29\left(\mathrm{t}, J 7.1 \mathrm{~Hz}, 3 \mathrm{H}, \mathrm{CH}_{3}\right)$ 1.59-1.85 (m, 5H), 2.21-2.47 (m, 3H), $2.26\left(\mathrm{~s}, 3 \mathrm{H}, \mathrm{CH}_{3}\right), 4.24(\mathrm{~m}$, $\left.2 \mathrm{H}, \mathrm{CH}_{2}\right), 5.52(\mathrm{~s}, 1 \mathrm{H}, \mathrm{ArCH}), 7.11-7.16(\mathrm{~m}, 4 \mathrm{H}), 7.84-8.22(\mathrm{~m}, 4 \mathrm{H}, \mathrm{ArH}) .{ }^{13} \mathrm{C}$ NMR $(100.6$ $\left.\mathrm{MHz}, \mathrm{CDCl}_{3}\right)$ 14.2, 20.5, 21.1, 21.4, 22.2, 22.5, 60.8, 67.7, 121.7, 126.8, 127.9, 129.2, 130.3, 133.4, 136.9, 144.5, 155.6, 165.7, 169.2. IR $\left(\mathrm{cm}^{-1}\right): 2971,1729,1657,1248,1091$. Anal. Calcd for $\mathrm{C}_{24} \mathrm{H}_{25} \mathrm{NO}_{3}$ : C, 76.77; H, 6.71; N, 3.73. Found C, 76.98; H, 6.85; N, 3.95\%.

4-[1-(4-Methylphenyl)-3-oxo-1,3,4,5,6,7-hexahydro-2H-isoindol-2-yl]benzamide

(5g). (Method A) Yield: $63 \%$, white powder, mp. $205-206{ }^{\circ} \mathrm{C}$ (toluene). $\mathrm{R}_{f}: 0.35 .{ }^{1} \mathrm{H} \mathrm{NMR}\left(\mathrm{CDCl}_{3}\right): \delta$ 1.61-1.90 (m, 5H), 2.18-2.44 (m, 3H), 2.27 (s, 3H, $\left.\mathrm{CH}_{3}\right), 5.61(\mathrm{~s}, 1 \mathrm{H}, \mathrm{ArCH}), 6.98-7,13$ (m, 4H, ArH), 7.25 (d, J 7.4 Hz, 2H), $7.52\left(\mathrm{~s}, 2 \mathrm{H}, \mathrm{CONH}_{2}\right), 7.59$ (d, J 7.3Hz, 2H). ${ }^{13} \mathrm{C}$ NMR $(100.6$ $\mathrm{MHz}, \mathrm{CDCl}_{3}$ ) 20.5, 21.4, 22.1, 22.4, 67.8, 126.9, 127.1, 128.7, 129.8, 131.0, 133.6, 138.1, 140.1, 155.8, 165.2, 168.2. IR $\left(\mathrm{cm}^{-1}\right): 2998,1666,1567,1243,672$. Anal. Calcd for $\mathrm{C}_{22} \mathrm{H}_{22} \mathrm{~N}_{2} \mathrm{O}_{2}:$, 76.28; H, 6.40; N, 8.09. Found C, 76.49; H, 6.65; N, 8.19\%.

4-[1-(4-Methylphenyl)-3-oxo-1,3,4,5,6,7-hexahydro-2 $\mathrm{H}$-isoindol-2-yl]benzenesulfonamide (5h). (Method B) Yield: 55\%, yellowish-white powder, mp. 213-215 ${ }^{\circ} \mathrm{C}(\mathrm{EtOH}) . \mathrm{R}_{f}: 0.20 .{ }^{1} \mathrm{H}$ NMR (DMSO-d $\left.d_{6}\right): \delta 1.63-1.97(\mathrm{~m}, 5 \mathrm{H}), 2.26\left(\mathrm{~s}, 3 \mathrm{H}, \mathrm{CH}_{3}\right), 2.33-2.44(\mathrm{~m}, 3 \mathrm{H}), 5.56(\mathrm{~s}, 1 \mathrm{H}$, $\mathrm{ArCH}), 7.01-7.11(\mathrm{~m}, 4 \mathrm{H})$ 7.84-8.09 (m, 4H, ArH). ${ }^{13} \mathrm{C} \mathrm{NMR}\left(100.6 \mathrm{MHz}, \mathrm{CDCl}_{3}\right)$ 21.3, 21.6, 21.8, 22.3, 22.6, 67.1, 121.9, 126.6, 127.8, 128.2, 128.7, 129.2, 133.4, 136.7, 140.2, 155.0, 165.3. IR $\left(\mathrm{cm}^{-1}\right): 2975,1677,1520,1327,1141$. Anal. Calcd for $\mathrm{C}_{21} \mathrm{H}_{22} \mathrm{~N}_{2} \mathrm{O}_{3} \mathrm{~S}: \mathrm{C}, 65.95 ; \mathrm{H}, 5.80 ; \mathrm{N}$, 7.32. Found C, 65.74; H, 5.66; N, 7.40\%.

\section{Acknowledgements}

The Authors would like to thank the Institute of Pharmaceutical Chemistry, University of Szeged, Hungary, and Alkaloida Chemical Company (Tiszavasvári, Hungary) for the IR and NMR spectroscopic measurements and for the elemental analyses. 


\section{References}

1. (a) Csende, F.; Szabó, Z.; Stájer, G. Heterocycles 1993, 36, 1809, and references therein. http://dx.doi.org/10.3987/COM-93-6366

(b) Csende, F.; Porkoláb, A.; Matíz, K.; Szabó, Z.; Csorvássy, I.; Frank, L. Sci. Pharm. 1999, 67, 149.

(c) Zsótér, T.T.; Hart, F.; Radde, I. C.; Endrenyi, L. J. Pharmacol. Exp. Ther. 1972, 180, 723.

(d) Csende, F.; Miklós, F.; Stájer, G. Curr. Org. Chem. 2012, 16, 1005, and references therein.

http://dx.doi.org/10.2174/138527212800194683

(e) Yamaguchi, T.; Yanagi, T.; Hokari, H.; Mukaiyama, Y.; Kamijo, T.; Yamamoto, I. Chem. Pharm. Bull. 1997, 45, 1518.

http://dx.doi.org/10.1248/cpb.45.1518

(f) Kanamitsu, N.; Osaki, T.; Itsuji, Y.; Yoshimura, M.; Tsujimoto, H.; Soga, M. Chem.

Pharm. Bull. 2007, 55, 1682.

http://dx.doi.org/10.1248/cpb.55.1682

2. (a) Nannini, G.; Giraldi, P. N.; Molgora, G.; Biasoli, G.; Spinelli, F.; Logemann, W.; Dradi, E.; Zanni, G.; Buttinoni, A.; Tommasini. R. Arzneim.-Forsch. 1973, 23, 1090.

PMid:4801034

(b) Fuccella, L. M.; Goldaniga, G. C.; Moro, E.; Tamassia, V.; Tosolini, G. P.; Valzelli, G. Eur. J. Clin. Pharmacol. 1973, 6, 256.

http://dx.doi.org/10.1007/BF00644742 PMid:4777259

(c) Huskisson, E. C.; Scott, J. Rheumatology 1979, 18, 49.

http://dx.doi.org/10.1093/rheumatology/18.1.49

(d) Brock-Utne, J. G.; Love, A. J.; Mankowitz, E.; Downing, J. W. S. Afr. Med. J. 1985, 68, 803.

3. (a) Lunn, M. R.; Root, D. E.; Martino, A. M.; Flaherty, S. P.; Kelley, B. P.; Coovert, D. D.; Burghes, A. H.; Man, N. T.; Morris, G. E.; Zhou, J.; Androphy, E. J.; Sumner, C. J.;

Stockwell, B. R. Chem. Biol. 2004, 11, 1489.

http://dx.doi.org/10.1016/j.chembiol.2004.08.024 PMid:15555999 PMCid:3160629

(b) Ellies, D.; Rosenberg, W. U.S. Patent 2010/0040628, 2010.

(c) Lee, H. J.; Lim, S. J.; Oh, S. J.; Moon, D. H.; Kim, D. J.; Tae, J.; Yoo, K. H. Bioorg. Med. Chem. Lett. 2008, 18, 1628.

http://dx.doi.org/10.1016/j.bmcl.2008.01.066 PMid:18242990

(d) Giblin, G. M. P.; Healy, M. P.; Livermore, D. G.; Price, H. S.; Swarbrick, M. E. U.S. Patent 2010/0273853, 2010. 
4. (a) Portevin, B.; Tordjman, C.; Pastoureau, P.; Bonnet, J.; De Nanteuil, G. J. Med. Chem. $\mathbf{2 0 0 0}, 43,4582$.

http://dx.doi.org/10.1021/jm990965x

(b) Lima, L. M.; Castro, P.; Machado, A. L.; Fraga, C. A.; Lugnier, C.; de Moraes V. L.; Barreiro, E. J. Bioorg. Med. Chem. 2002, 10, 3067.

http://dx.doi.org/10.1016/S0968-0896(02)00152-9

(c) Abdel-Aziz A. A.-M.; ElTahir K. E. H.; Asiri Y. A. Eur. J. Med. Chem. 2011, 46, 1648. http://dx.doi.org/10.1016/j.ejmech.2011.02.013 PMid:21388719

5. (a) Kapor, Á.; Stájer, G.; Bernáth, G. Acta Cryst. 1993, C49, 1967.

(b) Csende, F.; Jekő, J.; Porkoláb, A. Molbank 2011, M742.

6. Hinz, B.; Cheremina, O.; Brune, K. J. Federation Am. Soc. Exp. Biol. (FASEB) 2008, 22, 383.

7. Ermondi, G.; Caron, G.; Lawrence, R; Longo, D. J. Comput.-Aided Mol. Des. 2004, 18, 683. http://dx.doi.org/10.1007/s10822-004-6258-1

8. Kurumbail, R. G.; Stevens, A. M.; Gierse, J. K.; McDonald, J. J.; Stegeman, R. A.; Pak, J. Y.; Gildehaus, D.; Miyashiro, J. M.; Penning, T. D.; Seibert, K.; Isakson, P. C.; Stallings, W. C. Nature 1996, 384, 644. http://dx.doi.org/10.1038/384644a0 PMid:8967954

9. (a) Santana, L.; Teijeira, M.; Uriarte, E.; Teran, C.; Liñares, B.; Villar, R.; Laguna, R.; Cano, E. Eur. J. Pharm. Sci. 1998, 7, 161. http://dx.doi.org/10.1016/S0928-0987(98)00019-0

(b) Smeyers, Y. G.; Senent, M. L.; Villa, M. In Biological Applications of Quantum Chemistry Theory; Kubli-Garfias, C. Ed.; Research Signpost: Trivandrum, 2002; pp 1-15. 